\title{
HORSE PAWS AS RAW MATERIAL FOR FUR INDUSTRY
}

\author{
VERA RADNAEVA ${ }^{1}$, DMITRY SHALBUEV ${ }^{1}$, NIKOLAY SOVETKIN ${ }^{1}$, KHURELSUKH $^{2}$ \\ GAANBAATAR $^{2}$, SOLONGO KHOSBAYAR ${ }^{2}$, SUVDA DASHDORJ ${ }^{2}$, VICTORIY ALEKHINA ${ }^{1}$ \\ ${ }^{1}$ East Siberia State University of Technology and Management, Ulan-Ude, Russia, \\ shalbuevd@mail.ru \\ ${ }^{2}$ Company Khorol Collection, Ulaanbaatar, Mongolia
}

\begin{abstract}
Horse skin is used for processing various types of skin. However, paws of horse skin are not used as fur raw material. Usually they are burned or sent to landfills and may cause infectious diseases. It is possible to minimize negative impact on the environment by converting this waste into fur raw material. In cold regions of Russia high fur boots made of cattle and deer paws are very popular. The aim of the research is to study the possibility of using paws of horse skin as raw material for fur industry. Processing of horse paws based on well-known leather and fur processing technologies lead to semi-finished product characterized by increased stiffness and uneven properties on different skin parts. Such semi-finished product was not suitable for high fur boots manufacture. The aim of the research is to work out a new technology and study chemical and physico-mechanical properties. In the work various treatment options for horse paws and their properties are investigated: moisture content, amount of minerals and chromium oxide, $\mathrm{pH}$ of the aqueous extract, tensile strength, elongation at a voltage of $10 \mathrm{MPa}$, and stiffness are determined. The possibility of transferring horse paws from municipal solid waste into fur raw material is shown.
\end{abstract}

Key words: horse paws, technology, properties

\section{INTRODUCTION}

The Mongolian horse is a native breed of Mongolian horses. It is assumed that the breed has remained practically unchanged since the time of Genghis Khan. The nomads living in the traditional Mongolian style contain 4,2 million animals, which (data from 2019) exceeds the population of the country. In Mongolia, horses live outdoors all year round, with temperatures ranging from $30^{\circ} \mathrm{C}\left(86^{\circ} \mathrm{F}\right)$ in summer to $-40^{\circ} \mathrm{C}\left(-40^{\circ} \mathrm{F}\right)$ in winter (https://ru.wikipedia.org/wiki/Монгольская_лошадь). They graze and look for food on their own, serve as riding and transport animals, and are used both for the daily work of nomads and at races (Figure 1).
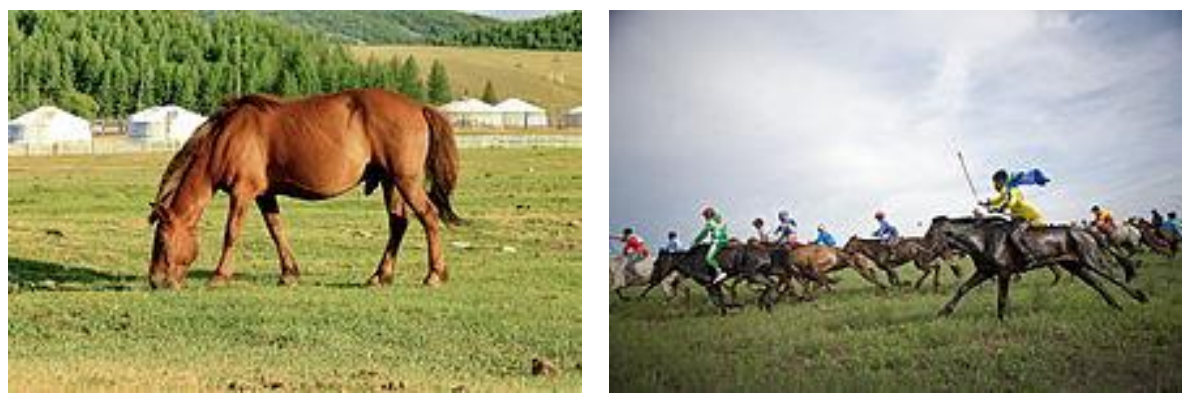

Figure 1. Mongolian horse (Equus ferus caballus)

In theory, the Mongolian horse is the basis for many other Asian horse breeds, including the Tuva, Akhal-Teke, Yunan, Japanese, and Jeju horse breeds. The national drink airag is produced from mare's milk. Some animals are slaughtered for meat. The 
skins of adult and semi-mature horses are considered leather raw materials. The skins of suckling foals and premature foals are classified as fur raw material. In contrast to the skins of cattle, horse skins are uneven in thickness (the front is thin, the khaz is thickened). The unevenness of horse skins in thickness is due to the fact that the forepart has a large number of sweat and sebaceous glands, rather thin fibers and bundles, and loose ligature. The significant difference between the forepart and the "khaz" causes the division of horse skins into parts, launching them into production in separate batches and processing them using various methods.

The border of dividing a horse hide into two parts is considered to be a hairline that runs perpendicular to the back line and is formed as a result of hair growth on the back in one direction and on the croup in the other direction (http://www.otkani.ru/leathercommodity/rawhide/6.html). In terms of histological structure, horse skins differ somewhat from cattle skins. The thickness of the epidermis is $2-3 \%$ of the total thickness of the dermis. The papillary layer of the dermis occupies over $30 \%$ of the entire thickness of the dermis and has a loose structure, since it contains numerous hair follicles. The reticular layer in horse skins is less developed than in cattle skins. Thin fibers form loose weaves over the entire area of the skin and only in the spiegel are they rather dense. The sweat and sebaceous glands are highly developed, and in the floors they form, as it were, a continuous layer, which reduces the strength of the attachment of the reticular and papillary layers in the skin.

In Russia (Sakha-Yakutia, Buryatia, Tyva, Kalmykia) and Mongolia, there is a traditional method of waste-free technology for processing horse products, including horse skins. Horse skins, as well as cattle skins, are used for the manufacture of various types of leather: "khaz" - for the production of sole leather, the forepart - for the manufacture of upper leather and Russia calf. They have a beautiful and delicate graining. The pullet hide, that is, the skins of young horses weighing from 5 to $10 \mathrm{~kg}$, with an area of 120-200 $\mathrm{dm}^{2}$, are mainly directed to obtain fur products (foal-sklizok) or on chrome-tanned and lacquered leather (foal). However, horse paws are not processed. Usually they are burned or sent to landfills, where, as a result of the combined action of abiotic and biotic factors, they undergo rotting. Putrefactive processes create conditions for the development of pathogenic microflora, which can contribute to the emergence of infectious diseases. It is possible to minimize the negative impact on the environment by processing this waste into a fur semi-finished product that can be used for sewing fur shoes (Shalbuev, 2018).

The production of paws from the skins of Mongolian horses according to the wellknown technologies of processing paws from the skins of cattle with the preservation of the hairline led to the production of a semi-finished product, characterized by increased rigidity, uneven properties of the topographic areas. Such a semi-finished product was not suitable for the manufacture of fur boots. One of the reasons that impede the use of horse paws is the lack of studies on the influence of processing parameters on the chemical and physical-mechanical properties of the leather tissue of the paws.

The aim of this work is to study the possibility of using horse paws as raw materials for the fur industry. To achieve this goal, it is necessary to investigate the influence of technological parameters on the chemical and physical-mechanical properties of horse paws.

https://doi.org/10.24264/icams-2020.III.14 


\section{OBJECTS AND METHODS}

The main objects of the study were undressed leather, dry salting skin and dressed paws from the skins of Mongolian horses. Horse paws preserved by dry salting were processed according to the scheme: soaking - pickling - neutralization - tanning - drying - finishing.

Enzymes are one of the well-known preparations allow to give softness to the skin tissue. It was of interest to study the effect of enzymes used at the stage of pickling paws from the skins of Mongolian horses on the physical and mechanical properties of the cut paws in order to obtain soft skin tissue. The following enzymes with proteolytic properties were used as enzyme preparations:

Enzym PKL from Lederplus (Spain) is an acidic (moderate) enzyme for processing fur, which is active at $\mathrm{pH}$ 3,0-6,0. Enzyme activity depends on the $\mathrm{pH}$ of the medium. It is white powder. It has a high penetrating power into the structure of leather tissue. It allows you to combine softening and pickling in one operation, dissolves and flushes out all ballast proteins from the leather tissue, providing faster penetration of chemical materials into the structure of the leather tissue (Sovenkin and Suleymanov, 2016).

Enzymacid ESP (Spain) stabilized cross-linked enzyme molecules have increased stability in an acidic environment (www.ericsonlab.ru/catalog/face_care/enzymacid/).

Betazim TK (Russia) has a high penetrating ability and facilitates the cleaning of the collagen structure from carbohydrates, lipids and soluble proteins, contributing to better penetration and distribution of acid throughout the entire area of the skins. It can work in an acidic environment in the $\mathrm{pH}$ range $2,8-3,0$. Using it in a pickle with a flow rate of $1-2 \mathrm{~g} / \mathrm{dm}^{3}$ makes it possible to increase the softness and plasticity of the skins, significantly reduce their weight, and also improve the uniformity of tanning (https://betachem.ru/pickling/betazim-tk).

The treatment of the paws of Mongolian horses was carried out according to five variants, differing in the composition of the pickle solution. Pickel solution in all variants contained sodium chloride in an amount of $50 \mathrm{~g} / \mathrm{dm}^{3}$, formic acid $5 \mathrm{~cm}^{3} / \mathrm{dm}^{3}$, Betol H-3 $-0,5 \mathrm{~cm}^{3} / \mathrm{dm}^{3}$. As an enzyme preparation, we used: an acidic enzyme for the treatment of fur brand Enzym PKL from Lederplus (Spain) - variant 1, Enzymacid ESP (Spain) - variant 2, Betazim TK (Russia) - variant 3. Variants 4 and 5 did not contain enzymes, but only acids of a different chemical nature: formic acid $5-10 \mathrm{~cm}^{3} / \mathrm{dm}^{3}$ option 4, formic acid $\left(5-10 \mathrm{~cm}^{3} / \mathrm{dm}^{3}\right)$ and sulfuric acid - option 5. It was assumed that enzymes, having a high penetrating ability, will help cleanse the collagen structure from carbohydrates, lipids and soluble proteins, thereby improving the penetration and distribution of acid over the entire area of the hides. Tanning was carried out with chromium (III) compounds.

Regulatory documents according to which the quality of leather fabric of horse paws was assessed are presented in GOST 4661-76 "Dressed fur sheepskins" (GOST 4661-76 - technical specification, 2002). The obtained values, characterizing the quality of the leather tissue of the paws of Mongolian horses, were compared with the normative data of TS - 205 RSFSR 17.203 - 79 "Camus dressed". The choice of these regulatory documents is due to the lack of regulated methods for determining the chemical and physical-mechanical properties of dressed horse paws. The rigidity of the leather tissue of the horse paws was determined according to the method developed at the Department of "Leather and Fur Technology Water Resources and Commodity Research" ESSUTM (Sovetkin and Dumnov, 1988). 


\section{RESULTS AND DISCUSSION}

The conclusion about the suitability of the horse paws made from the skins of Mongolian horses for sewing winter boots of high fur boots is made on the basis of a comprehensive analysis of physical, mechanical and chemical properties, as well as trial sewing of high fur boots. It was noted above about the increased rigidity of the leather tissue of the dressed horse paws when using the technique for processing paws from cattle skins.

Table 1 shows the indicators of the chemical composition of the paws from the skins of Mongolian horses of the different variants.

Table 1. Indicators of the properties of paws from the skins of Mongolian horses of different variants

\begin{tabular}{|c|c|c|c|c|c|c|}
\hline \multirow[t]{2}{*}{ №/№ } & \multirow[t]{2}{*}{ Variant } & \multicolumn{3}{|c|}{$\begin{array}{c}\text { Mass fraction, \% (absolutely dry } \\
\text { substance) }\end{array}$} & \multirow{2}{*}{$\begin{array}{c}\mathrm{pH} \\
\text { water } \\
\text { extract }\end{array}$} & \multirow[t]{2}{*}{$\begin{array}{l}\text { Shrinkage, } \\
{ }^{\circ} \mathrm{C}\end{array}$} \\
\hline & & moisture & $\begin{array}{c}\text { mineral } \\
\text { substances }\end{array}$ & $\begin{array}{l}\text { chromium } \\
\text { oxide }\end{array}$ & & \\
\hline 1 & Enzym PKL & $13,3 \pm 0,1$ & $14,7 \pm 0,2$ & $4,5 \pm 0,1$ & $3,3 \pm 0,1$ & $93 \pm 4$ \\
\hline 2 & $\begin{array}{l}\text { Enzymacid } \\
\text { ESP }\end{array}$ & $12,3 \pm 0,2$ & $14,8 \pm 0,3$ & $4,8 \pm 0,1$ & $3,2 \pm 0,1$ & $96 \pm 2$ \\
\hline 3 & Betazim TK & $12,4 \pm 0,2$ & $14,5 \pm 0,1$ & $4,7 \pm 0,1$ & $3,1 \pm 0,1$ & $97 \pm 1$ \\
\hline 4 & Formic Acid & $12,2 \pm 0,1$ & $14,9 \pm 2,2$ & $3,9 \pm 0,1$ & $2,9 \pm 0,1$ & $98 \pm 1$ \\
\hline 5 & $\begin{array}{c}\text { Formic Acid } \\
\text { and Sulfuric } \\
\text { Acid }\end{array}$ & $12,5 \pm 0,3$ & $15,7 \pm 0,3$ & $4,3 \pm 0,2$ & $3,1 \pm 0,1$ & $97 \pm 3$ \\
\hline $\begin{array}{l}\text { Normative } \\
\text { document }\end{array}$ & $\begin{array}{c}\text { TS - } 205 \\
\text { RSFSR } \\
17.203-79 \\
\text { "Camus } \\
\text { dressed" }\end{array}$ & $10-14$ & None & None & $3,5-7,0$ & $>63$ \\
\hline
\end{tabular}

The choice of TS - 205 RSFSR 17.203 - 79 "Camus dressed" as a normative document is due to the fact that at the moment in Russia this document is the only one that regulates these indicators. As can be seen from Table 1, the moisture content of the dressed paws is within the limits allowed by TS 205 RSFSR 17.203 -79 It should be noted that the moisture content of all leather and fur products is usually regulated in the range of $12-14 \%$ or $12-16 \%$, therefore, according to this indicator, the paws made from horse skins correspond to the accepted standards.

Analysis of the data obtained showed that the composition of the pickle bath does not have a significant effect on the content of minerals and chromium oxide in leather tissue, while the mass fraction of chromium oxide is in the range of $3,9-4,5 \%$, and mineral substances $-14,5-15,7 \%$. The data in Table 1 show the high heat resistance of the samples of the paws for almost all treatment options $\left(93-98^{\circ} \mathrm{C}\right)$, which indicates a strong bond of chromium compounds with the functional groups of the protein. It should be noted that for «kamus» made from reindeer skins, the lower limit of heat resistance of leather fabric is $63^{\circ} \mathrm{C}$, which is considered acceptable for sewing winter shoes.

Therefore, despite the lack of normative data on the mass fraction of chromium oxide and, knowing about the known correlation between this indicator and the shrinkage temperature, the value of this indicator can be considered sufficient to obtain 
high-quality products. From the data in Table 1 , it can be seen that the $\mathrm{pH}$ of the aqueous extract for the prototypes is somewhat lower than the regulated value. The lowest $\mathrm{pH}$ was observed for paws pickled with formic acid. The obtained data on the $\mathrm{pH}$ of the aqueous extract indicate the need to correct the technological parameters at the tanning-neutralization.

The results presented in Table 1 showed no significant difference in chemical properties for horse paws isolated using different enzymes, formic acid and its mixture with sulfuric.

Table 2 shows the results of the influence of the composition of the pickle on the physico-mechanical properties of the paws from the skins of Mongolian horses.

Table 2. Results of physical and mechanical tests of Mongolian horse paws of different variants

\begin{tabular}{|c|c|c|c|c|c|c|}
\hline \multirow[b]{2}{*}{ Data } & \multicolumn{5}{|c|}{ Variant } & \multirow{2}{*}{$\begin{array}{l}\text { TS - } 205 \\
\text { RSFSR } \\
17.203-79 \\
\text { "Camus } \\
\text { dressed" }\end{array}$} \\
\hline & $\begin{array}{l}\text { Enzym } \\
\text { PKL }\end{array}$ & $\begin{array}{l}\text { Enzymacid } \\
\text { ESP }\end{array}$ & $\begin{array}{c}\text { Betazim } \\
\text { TK }\end{array}$ & $\begin{array}{c}\text { Formic } \\
\text { acid }\end{array}$ & $\begin{array}{l}\text { Formic } \\
\text { Acid and } \\
\text { Sulfuric } \\
\text { Acid }\end{array}$ & \\
\hline Stiffness, H & 1,8 & 1,8 & 1,7 & 1,8 & 1,6 & - \\
\hline $\begin{array}{l}\text { Elongation at a stress } \\
\text { of } 10 \mathrm{MPa}, \%\end{array}$ & 67,2 & 60,7 & 64,4 & 67,2 & 65,3 & - \\
\hline $\begin{array}{l}\text { Tensile strength, } \\
\mathrm{MPa}\end{array}$ & 17,8 & 19,6 & 18,7 & 17,8 & 23,3 & - \\
\hline $\begin{array}{l}\text { Elongation at break, } \\
\%\end{array}$ & 93,0 & 89,0 & 90,7 & 95,6 & 96,3 & - \\
\hline
\end{tabular}

The results of physical and mechanical tests showed that the paws were distinguished by high strength - tensile strength ranged from 17,8 to $23,3 \mathrm{MPa}$, elongation at break was $89,0-96,3 \%$, elongation at a stress of $10 \mathrm{MPa} 64,4-67,2 \%$. At the same time, it should be noted that the rigidity of all samples was practically the same. The organoleptic assessment of the stiffness of the paws showed the need to improve the method for determining the stiffness.

Table 3 shows the data of organoleptic evaluation of paws horse of the different variants. A score of 1 was given to samples with the minimum stiffness, and a score of 5 was the samples with the maximum stiffness.

Table 3. Organoleptic evaluation of horse paws of the different variants

\begin{tabular}{ccc}
\hline Variant & Score & Stiffness, H \\
\hline 1 & 1 & 1,76 \\
2 & 3 & 2,79 \\
3 & 2 & 2,29 \\
4 & 4 & 3,02 \\
\hline
\end{tabular}

Comparison of the results of the organoleptic evaluation of the cut paws from the skins of Mongolian horses with the stiffness indicators determined on the device showed a correlation relationship - the correlation coefficient is 0,98 .

Analyzing the results of physical and mechanical tests and the chemical properties of the cut paws from the skins of Mongolian horses, it was concluded that they can be used for sewing winter shoes (Figure 2). 

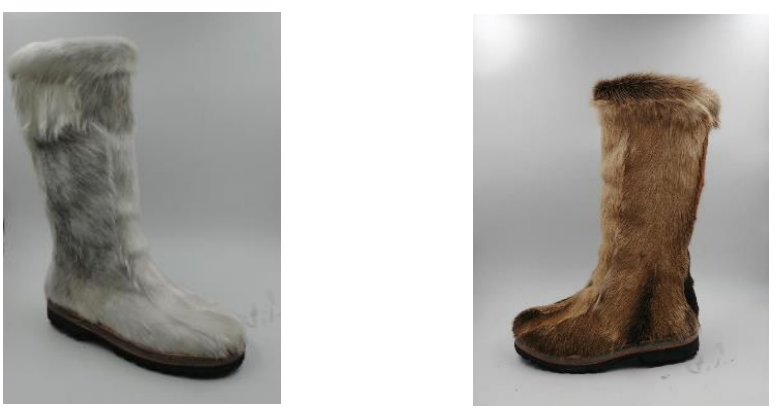

Figure 2. Winter boots from paws of the Mongolian horse

Thus, the new fur material obtained from the paws of the skins of Mongolian horses had optimal functional and technological properties, was soft and flexible, which makes it possible to recommend it for "untov" - winter fur boots.

\section{CONCLUSION}

1. The possibility of using horse paws as a raw material for the fur industry is shown.

2. It was revealed that the chemical and physical-mechanical properties of the paws from the skins of Mongolian horses have optimal functional and technological properties, which determines their suitability and manufacturability when sewing winter high fur boots.

3. It has been established that dressed paws from the skins of Mongolian horses are a new material for sewing winter shoes, and the raw materials can be transferred from solid household waste to the category of raw materials for fur industry.

\section{REFERENCES}

GOST 4661-76 (2002), "Dressed fur sheepskins. Technical specifications." - M.: Publishing house of standards, $11 \mathrm{p}$.

Shalbuev, Dm., Tumurova, T., Radnaeva, V. and Manieva, V. (2018), “On destruction of fatty substances by prokaryotic organisms isolated from fur production waste water.”, International Journal of Civil Engineering and Technology (IJCIET), 9(11), 1918-1926

Sovenkin, N.V. and Suleymanov, R.G. (2016), "Study the influence of enzymes in the pickle on consumer properties sheepskin", in Proceeding of the XII International scientific and practical conference: Leather and fur in the XXI century: technology, quality, ecology, education. - Ulan-Ude: ESSUTM Publishing House, P. 397-401.

Sovetkin, N.V. and Dumnov, V.S. (1988), RU Patent 1395983, IPC GO1N 3/42. Publ. 05/15/1988 "Device for determining the stiffness of elastic materials".

*** https://betachem.ru/pickling/betazim-tk/ (Date 08/25/2020)

*** https://ru.wikipedia.org/wiki/Монгольская_лошадь (Date 08/19/2020) Mongolian Horse URL

*** https://www.ericsonlab.ru/catalog/face_care/enzymacid/ (Date 08/25/2020)

*** http://www.otkani.ru/leathercommodity/ rawhide/6.html (Date 08/19/2020) Characteristics of raw hides. Use of horse hides. 